\title{
KLASIKK DÖNEM OSMANLI TARİH YAZIMINDA OTO SANSÜR VE ÇARPITMA: BEŞ OLAY BİR SONUÇ
}

\section{ÖZ}

Yunus İNCE*

Tarih için birçok tanım yapılmıştır. Her tanımda tarihin bir yönüne işaret edildiği görülür. Cicero'ya göre; "tarih, insanliğın hafızasıdır". Bir birey için hafızası ne kadar önemliyse, insanlık için de tarih o kadar önemlidir. Cicero'dan bu yana hafıza ile tarih arasında anolojik bir ilişki olduğu düşünüle gelmiștir. Dolayısıyla tarihçi de hafizayı koruyan, geçmişi muhafaza eden bir bellek muhafizı konumundadır. Ancak hakikatte tarih, geçmişin tamamını sonraki nesillere anlatamaz ya da muhafaza edemez. Zira geçmişte yaşanan her hadise kayıt altına alınamaz. Tarihçi, geçmişin içinden bir kısmını seçip satırlarına taşıyarak neyin tarih olabileceğine neyin ise tarih olması gerekmediğine karar veren kişidir ve her tercih/seçim aynı zamanda bir vaz geçiştir. Bu anlamda geçmişin bir kısmı tarih olarak sonraki kuşaklara aktarılır ve bu durum tarihin doğasından kaynaklanır. Ancak bazen tarihçi bazı hadiseleri bile isteye ya da bir baskı nedeniyle görmezden gelir ya da olduğundan daha farklı olarak aktarmayı tercih eder. Susmak/yazmamak eğer dışarıdan bir baskı yok ise oto sansür, var olan gerçekliği daha farklı şekilde göstermek de çarpıtma olarak kabul edilebilir. Bu çalışmada Osmanlı tarihinin klasik döneminde (1300-1600) devrin tarih yazarları tarafından yazılmayan ya da olduğundan farklı gösterilen beş olayı yazmayanların/yaz[a]mayanların kimler olduğu, yazıl[a]mayanın $n e$ olduğu, bahsi geçen hâdiselerin nerede ve ne zaman geçtiği, oto sansürün ya da çarpıtmanın nasıl ve niçin yapıldığı sorularının cevabı bir makale ölçeğinde ele alınmaya çalışılacaktır.

Anahtar Kelimeler: Osmanlı Devleti, tarih yazımı, hafıza, oto sansür, çarpitma

\section{SELF-CENSORSHIP AND DISTORTION IN CLASSICAL PERIOD OTTOMAN HISTORIOGRAPHY: ONE CONCLUSION FOR FIVE INCIDENTS}

\section{ABSTRACT}

Many definitions have been made for history and it is seen that an aspect of history is referred to in each definition. According to Cicero,; "history is the memory of mankind". Just as memory is extremely important for an individual, so is history, for humanity. It has been thought since the time of Cicero that there is an analogical

\footnotetext{
* Dr. Öğr. Üyesi, Muğla Sitkı Koçman Üniversitesi Edebiyat Fakültesi Tarih Bölümü, yunusince@mu.edu.tr, ORCID: 0000-0002-7942-7407
} 
connection between memory and history. Therefore, a historian is in the position of a memory guardian who protects memory and preserves the past. In reality, however, history cannot tell all of the past to the future generations or keep it, because not all incidents that occurred in the past can be recorded. A historian is a person who decides what can qualify as history and what cannot, by selecting some of the past events, and writing them down and indeed each preference/choice is at the same time a renunciation. In this sense, a certain part of the past is conveyed as history to subsequent generations and this state of affairs arises from the very nature of history. Yet, sometimes a historian may ignore some events either purposely or due to some pressure or prefers to tell them in a way that they are in conflict with the real facts. Keeping silent/not writing down is considered to be self-censorship if there is no external pressure, and depicting the existing reality in a different way can be regarded as distortion. In this study, five incidents in the classical period of the Ottoman history (1300-1600) which were either not recorded by historians of the time or described in a way contrary to the facts will be dealt with within the scope of an article seeking answers to the questions; who were those who did/could not write them down, what was it that was not written down, where and when the incidents in question took place, and how and why self-censorship or distortion was performed.

Key Words: Ottoman State, historiography, memory, selfcensorship, distortion

\section{Giriş}

İster gerçek, isterse kurgu olsunlar Leyla ile Mecnun, Kerem ile Aslı, Ferhat ile Şirin, Tahir ile Zühre hikâyeleri aşkın tarihinde sadece birer örnek hükmündedir. Dünya tarihinde aşkından dolayı ızdırap çeken şahıslar bunlardan ibaret değildir. Aynı şekilde Achilleus, Zaloğlu Rüstem ya da Afrasiyab da dünya savaş tarihinin yegâne kahramanları değillerdir. Dünya tarihinde savaş meydanlarında vatanları, inançları ve idealleri için hayatlarını kaybeden milyonlarca insan vardır. Ancak bunların çok az bir kısmı hatırlanır. Hatta çoğunun müstakil bir mezarı-mezar taşı dahi olmamış, bir toplu mezara defnedilmişler ve hatıraları da benzer bir toptancılıkla "meçhul asker" kavramı içerisinde ifade edilip geçilmiştir. Nitekim dünyanın birçok ülkesinde bulunan meçhul asker anıtları, hatırası anılmayan insanların çokluğunun da delilidir. 
Yazıları ile Annales Ekolünün olușmasında etkili olan Jules Michelet, bir tarihçinin vazifesini şu șekilde dile getirir: "Hiçbir zaman söylenmemiş, kalbin derinliklerinde kalmış sözleri (kalbinizi yoklayın, orada sözcükler bulacaksınız) duymak gerekir; tarihin sessizliklerini, tek söz etmediği ve tam da en trajik zamanları olan șu korkunç suskunluk anlarını konușturmak gerekir. Ancak o zaman, ölüler mezarlarına razı olacaklar. Yazgılarını anlamaya, onun uyumsuz, yürek parçalayıcı notalarını, daha yumușak bir armoni içinde eritmeye başlayacaklar. Gölgeler sakinleşip yatışıyorlar; kül kavanozlarının kapaklarının kapatılmasına izin veriyorlar. Arkadaşça eller tarafindan uğurlanıp uzaklașıyorlar, yeniden uykuya dalıp rüyalarına geri dönüyorlar. Geçmiș zamanları tașıyan değerli kavanozu tarihin rahipleri, ne derin bir acımayla, ne șefkatli bir özenle (bunu ancak kendileri bilir), kendi babalarının ve oğullarının küllerini tașırmışçasına taşıyorlar ve elden ele aktarıyorlar. Ama taşıdılkları bizzat onlar değil mi zaten "1 Jules Michelet, bu satırlarında ölümün tüm insanların ortak kaderi olduğuna ve esasen gerçek ölümün unutulmak olduğuna ișaret eder. Bu yargısında yalnız değildir bir eski Mısır şiiri de benzer düșünceleri dile getirir:

"İnsan ölüp gider, toprak olur eti, kemiği,

Çökmek ve çürümek herkesin alın yazısl,

Ama okurlar var oldukça yazanlar yaşar sonsuz."2

Gerek Eski Mısırlı meçhul şairin dizeleri, gerekse Jules Michelet'in ifadeleri, gerçek ölümün unutulmak olduğunu ifade eder. Öyleyse öldükten sonra da hatırlanmak/unutulmamak için ne yapılabilir?

Benjamin Franklin, bu soruya şu cevabı verir; "Ölür ölmez unutulmak ve çürümek istemiyorsanız ya okunmaya değer bir kitap yazın, ya da yazılmaya değer işler başarın."3 Bu gerçeğin farkında olan birçok imparator, kral, hükümdar ya da padişah kendileri öldükten sonra da adlarının yaşaması ve yaptıklarının insanlar tarafından bilinmesi için tarih eserleri yazdırmıșlar, kendilerine ve icraatlarına dair bilgiler veren kitabeler diktirmişlerdir. Zira "tarih, insanlığın

\footnotetext{
${ }^{1}$ Patrick Cabanel, "Jules Michelet", Tarihçiler, der. Véronique Sales, çev. Elif Bildirici, İletişim Yayınları, İstanbul, 2016, s. 26.

2 Talât Sait Hamlan, Güneş-Tanrı ile Sevgi Ozanı Eski Mısır'dan Şiirler, Yapı Kredi Yayınları, İstanbul 1995, s. 47.

${ }^{3}$ If you wou'd not be forgotten as soon as you are dead and rotten, either write things worth reading, or do things worth the writing." Benjamin Franklin, Poor Richard's Almanac, Barnes\&Nobles Book, New York, 2004, p. 59.
} 
hafizasıdır"4 ve hafiza-i beșer nisyan ile malüldür. ${ }^{5}$ Bu kusurun ortadan kaldırılması için geçmiş̧in sıkça insanoğluna bir ibret vesilesi olarak sunulması gerekmiştir. Belleğin/hafızanın geçmiş olmaktan çıkarılıp tarih haline getirilmesi için yazılı bir anlatı haline dönüştürülmesi zaruridir. ${ }^{6}$ Bütün bu ifadelerden sonra şunu söylemek yerinde olacaktır. Bir şahıs için hafızasının arz ettiği önem neyse, bir millet için de tarih aynı ehemmiyettedir. Geçici olarak hafızasını kaybeden (Amnesia) ${ }^{7}$ bir insan için yaşamını devam ettirebilmesi için hafızası ne kadar önemliyse bir millet için de tarihsel hafıza o kadar önemlidir.

Muhtemelen bu ehemmiyetinden olsa gerektir ki, Türkçede gündelik dilde içerisinde tarih kelimesi geçen birçok deyim ya da söz öbeği olduğu görülür: tarih yazmak, tarih atmak (koymak), tarih düşürmek, tarihe geçmek, tarihe karışmak, tarih tarafindan adı yazılmak vb. gibi. Tarih yazmak, tarihe mâl olmak ya da tarihe geçmek hatırlanmayı ima/ifade eden deyimler iken, tarih olmak, tarihe karışmak ya da tarihin meçhuliyetinde yok olup gitmek daha ziyade unutulmayı ima/ifade eden deyimlerdir. Bir kavram (tarih) nasıl olur da hem hatırlanmayı hem de unutulmayı ifade edebilir?

Esasen tarih kavramı hatırlamayı olduğu kadar unutmayı da ifade eder. Tarihin yalnızca hatırlamak ile ilişkilendirilmesi bu kavrama yüklenen yanlış anlamdan meydana gelmektedir. Zira tarihin geçmişte meydana gelmiş her şeyi olduğu gibi kaydettiği düşüncesi bir vehimden başka bir şey değildir, dahası bu mümkün de değildir. Tarih geçmişin yalnızca seçilen bir kısmının hikâyesidir. $\mathrm{Bu}$ anlamda geçmişte meydana gelmiş bir hadisenin tamamı hiçbir zaman tamamıla aktarılamaz. Geçmişin bilgisi aktarılırken ki durum bir futbol maçına benzetilebilir. Nasıl ki maçı aktaran spiker aynı sahada bulunan tüm futbolcuların hareketlerini aktarmiyor ancak topu alan, almaya çalışan ve topla oynayan oyuncuların fiillerini aktarıyorsa, tarihçi de geçmişteki hadiseleri naklederken bu hadiseler içerisinden seçtiği bazı kısımları aktarır. Esasen bu bir zorunluluktur. Zira aksi durumda bir maçtaki yirmi iki futbolcunun tüm hareketlerinin aynı

\footnotetext{
${ }^{4}$ Marcus Tullius Ciceronis, Ad Qintum Fratrem Dialogi Tires de Oratore, ed. James Luce Kingsley, Novi Porte Publisher, Basım yeri yok 1839, p. 72.

5 "Geçmiş kuşaklar anımsanmıyor, gelecek kuşaklarda kendilerinden sonra geleceklerce anımsanmayacak" (Vaiz 1/11), Kutsal Kitap-Eski ve Yeni Antlaşma (Tevrat, Zebur, İncil), Kitab-ı Mukaddes Şirketi Yayınları, İstanbul, 2008, s. 694.

6 Enzo Traverso, Geçmişi Kullanma Klavuzu, Tarih, Bellek, Politika, çev. Işılk Ergüden, Versus Yayınları, İstanbul, 2009, s. 9-31.

7 Hugo J. Spiers- Eleanor A. Maguire1-Neil Burgess "Hippocampal Amnesia", Neurocase,VII, Oxford University Press, London, 2001, pp. 357-382.
} 
anda anlatmaya çalıșılması ya da geçmişteki hadiseye dair tüm ayrıntıların aktarılması çabası, netice itibariyle kargaşa/kaos ve anlamsızlık üretir. 8 Öyleyse tarih her ne kadar geçmişin bilgisinin kayıt altına alınmasını ve geleceğe aktarılmasını ifade etse de neticede burada yazıya geçirilen geçmiş, geçmişteki hadisenin tıpatıp aynısı değildir ve geçmişin ancak bir kısmı olabilir. Geçmiş geleceğe aktarılırken, geçmişin bir kısmının göz ardı edilmesi ya da bir kısmının dikkate alınması tarihin yapısından/doğasından kaynaklanan bir durumdur. Neyin tarih olacağına karar verme kudretine sahip olan tarihçi bazı tercihlerde bulunur ve her tercih aynı zamanda bir vazgeçiștir. Yani bazı hadiseleri ya da konuları anlatılmaya ya da hatırlanmaya değer olarak kabul etmesi, bazı olayları ya da konuları anlatılmaya ya da hatırlanmaya değmeyeceğini düşündüğü anlamına gelir. Tarihin bu özelliği bahsi geçen tercihi/seçimi yapacak tarihçiye büyük bir kudret bahşeder ki, bu nedenle bazı yazarlara göre esasen "tarih yoktur, tarihçiler vardır."

$\mathrm{Bu}$ seçim neticesinde geçmişin bir kısmı unutulmaya terk edilir ya da görmezden gelinir. Tarih, toplumsal belleğin yok olduğu noktada başlayan ve kayıt altına alınmasına karar verilen geçmişin bir kısmının hatırlanması için çaba gösteren bir bilim dalı ${ }^{10}$ olsa da bazen de tarihçiler bazı hadiseleri bile isteye görmezden gelirler.

$\mathrm{Bu}$ anlamda her hatırlama ya da unutma eylemi, tarihsel belleği, kollektif belleği ya da grup belleğini etkileme amacı taşır. ${ }^{11}$ Çağlar boyunca bazen bireyler bazen de siyasi otorite sahipleri farklı nedenlerle kitapları ya da resmi belgeleri yakarak ya da yok ederek bazı bilgileri tarihsel hafızadan silmeye çalışmışlardır. Bu anlamda tarih boyunca birçok imparator, kral, hükümdar ya da padişah kendisini ölümsüz kllarak, rakiplerini/düşmanlarını

8 Michel-Rolph Troillot, Geçmişi Susturmak Tarihin Üretilmesi ve Íktidar, çev. Sezai Ozan Zeybek, İthaki Yayınları, İstanbul, 2015, s. 75-86.

9 Paul Ricoeur tarafından Lucien Febvre'den yapılan alıntı oldukça meșhur olmuștur. Paul Ricoeur, The Contribution of French Historiography to the Theory of History, Oxford Clarendon Press- Oxford University Press, New York, 1980, s. 9.

10 Jan Assmann, Kültürel Bellek, Eski Kültürlerde Yazı, Hatırlama ve Politik Kimlik, çev. Ayșe Tekin, Ayrıntı Yayınları, İstanbul, 2015, s. 51-53; Maurice Halbwachs, Hafızanın Toplumsal Çerçeveleri, çev. Büşra Uçar, Heretik Yayınları, Ankara, 2016, s. 76-86; John Tosh, Tarihin Peșinde, Modern Tarih Çalıșmasında Hedefler, Yöntemler ve Yeni Doğrultular, çev. Özden Arıkan, Tarih Vakfı Yurt Yayınları, İstanbul, 2005, s. 3.

11 Patrick J Geary, Phantoms of Remembrance: Memory and Oblivion at the end of the First Millennium, Princeton University Press, Princeton-New Jersey, 1994, s. 25-26. 
yokluğa/unutulmaya mahkûm etmeye çalıșmıștır.12 Zira "anılardan yok olmak şimdiye değin hep "ikinci ölüm" olarak adlandırllmıştır."13 Burada bahsi geçen çaba, unutturmak olarak tanımlanabilir.

Bunun dişında bir de bireylerin kendilerine acı veren travmatik hatıralarını bilinçten uzak tutmak/geri çevirmek ve yaşamını devam ettirebilmek amacıyla geliştirdikleri bir savunma mekanizması vardır ki buna bastırmak adı verilir. Bastırmada da acı veren hatıraların bilinçaltına atılması ya da unutulması durumu vardır. ${ }^{14}$

Bastırma dışında bireyler bazen bazı șeyleri bile isteye görmezden gelebilirler. Eğer görmezden gelme eylemini yapan kişi tarihçi ise, yazmamak ya da susmak yoluyla yaptığı eyleme oto sansür denilebilir. Eğer tarih yazarına dışarıdan doğrudan bir baskı yok ise ya da eserini sunacağı devletlülerin bu eseri beğenmeyeceği endişesi ile bazı olayları görmezden geliyor ise, bu eylemi oto sansür olarak adlandırılabilir. Var olan tarihi gerçeklik biraz değiştirilerek anlatılıyor ise bu duruma da çarpıtma denilebilir. Şimdi konumuz olan klasik dönem Osmanlı tarih yazımındaki beş olay üzerinden oto sansürün ve çarpıtmanın nasıl yapıldığına değinelim.

\section{I- Hâkimiyet Alametlerinin Alınması ve Bağımsızlık}

Erken dönem Osmanlı kroniklerinde Moğol Askerleri ile Anadolu Selçuklularını karşı karşıya getiren bir savaştan bahsedilir. Bu mücadele sırasında Anadolu Selçuklu ordusunun başında kaçıncısı olduğu ifade edilmeyen Sultan Alâeddin vardır. Sultan Alâeddin Moğol askerleri üzerine yürümeden önce Karacahisar'ı kuşatmıştır. Kuşatma sırasında Osmanlılar da Anadolu Selçukluları safında savaşan gaziler arasındadırlar. Sultan Alâeddin, Moğolların topraklarına girdiğini öğrenince; Sultan Alâeddin şu sözlerle Osman Gazi'ye hitap eder ve

\footnotetext{
12 Paul Connerton, Toplumlar Nasıl Anımsar?, çev. Alaeddin Şenel, Ayrıntı Yayınları, İstanbul, 2014, s. 29-33. Bu konuda daha geniş iki çalışma için bkz. Fernando Báez, Kitap Kıyımının Evrensel Tarihi, çev. Tolga Esmer, Can Yayınları, İstanbul, 2018; Lucien X. Polastron, Kitap Yakmanın Tarihi, çev. Aziz Ufuk Kılıç, Everest Yayınları, İstanbul, 2011.

13 Douwe Draaisma, Unutmanın Kitabı, Rüyalarımızı Neden Hemen Unuturuz, Anılarımız Neden Sürekli Değişir?, çev. Dilman Muratoğlu, Yapı Kredi Yayınları, İstanbul, 2012, s. 17.

14 Sigmund Freud, Bastırma ve Bastırılanın Geri Dönüşü, çev. Oya Kasap, Telos Yayınları, İstanbul, 2015; Draaisma, Unutmanın Kitabl, s. 145, 156-157; Anna Freud, Ben ve Savunma Mekanizmaları, çev. Yeşim Erim, Metis Yayınları, İstanbul, 2015, ss. 41-43.
} 
beraberinde getirdiği silahlarla birlikte kuşatmanın sorumluluğunu da ona bırakır: "Oğul, Osman Gâzi! Sende sa'âdet nişanları çokdur. Sana ve neslüne âlemde mukâbil olıcl yokdur. Benüm du'âm, Allah'un inâyeti ve evliyânun himmeti ve Muhammed'in mu'cizâtı senünle biledir." Karacahisar ele geçirildikten sonra Osman Gazi, müjdeyi iletmesi için yeğeni Ak Temür'ü Sultan Alâeddin'e gönderir. Sultan Alâeddin'in bu müjde karşısındaki sevincini Âșıkpașazâde şu șekilde aktarır: “Sultanın ferahlı̆ğ ziyâde oldu. Ak Temür'e mübâlağa atalar ve gaza yarakları bile verdi. Ak Temür dahi sancağı getürdi. Íkindi vaktiydi. Hema[n] nevbet uruldu. Osman Gâzi ayağın durdu nevbet urulunca. Tâ şimdiye değin Âl-i Osman seferde nevbet ursalar ayağın dururlar."15

Âșıkpaşazâde Tarihi dışındaki birçok ilk dönem Osmanlı kroniğinde Karacahisar'ın alınmasının ardından Sultan Alâeddin'den gelen sancak, silah gibi bağımsızlık alametlerinden ve nevbet vurulmasından bahseder. Yine ilk dönem kroniklerinde bu noktadan sonra Osman Gazi, bağımsız hareket etmeye bașladığını bilgisini bulmak da mümkündür. ${ }^{16}$ Âşıkpaşazâde Karacahisar ele geçirildikten sonra, Germiyanoğlu topraklarından gelenlerin Karacahisar'daki boş evlere yerleştirilmesi, insanların gündelik ihtiyaçlarını temin edebilmeleri için pazar kurulması, pazardan vergi alınması, alışverişlerde usulsüzlüklerin önüne geçilmesi ve ibadet ihtiyaçları için kiliselerin camiye çevrilmesi gibi ișlerle meşgul olduğunu anlatır. Karacahisar'da yaşayan reaya șehirdeki hukukî düzenleme, denetleme ve adalet dağıtımı gibi ihtiyaçların temini için bir kadıya, toplu olarak ibadet edilebilmesi için bir imama ihtiyaç olduğunu Tursun Fakih'e bildirirler. Tursun Fakih, Şeyh Ede Bâli ile bu ihtiyaçların nasıl giderilebileceği hakkında konuşurken, Osman Gazi gelir ve şöyle söyler: "Her ne kim size gerekdür, anı edün" der. Tursun Fakı eydür: "Hanum! Sultandan izin gerekdür" der. Osman Gâzi eydür: "Bu șehri ben kendü kllıcumla aldum. Sultanun bunda ne dahli var kim andan izin alam. Ona sultanlık veren Allah bana dahi gazâyile hanlık verdi. 'Ve ger minneti şu sancağise ben hod sancak götürüp kâfirile uğraşmadum' der.

15 Âșıkpaşazâde, Âșıkpaşazâde Tarihi [Osmanlı Tarihi (1285-1502)], (Kısaltma: Âșıkpașazâde Tarihi), haz. Necdet Öztürk, Bilge Kültür Sanat Yayınları, İstanbul, 2013, s. 15-18.

16 Şükrullâh, Behcetü't-Tevârîh-Tarihin Aydınlı̆ğnda, çev. Hasan Almaz, Mostar Yayınları, İstanbul, 2013, s. 377; Mevlâna Mehmed Neșrî, Cihânnümâ [Osmanlı Tarihi (1288-1485)], haz. Necdet Öztürk, Çamlıca Basın Yayım. İstanbul, 2008, s. 50-51; Hadidî, Hadidî Tarihi [Manzum Osmanlı Tarihi] (1285-1523), haz. Necdet Öztürk, Bilge Kültür Sanat Yayınları, İstanbul, 2015, s. 37-41; Müneccimbașı Ahmed b. Lütfullah, Camiü'd-Düvel (Osmanlı Tarihi 1299-1481), (Kısaltma: Camiü'd-Düvel), haz. Ahmet Ağırakca, İnsan Yayınları, İstanbul, 1995, s. 67-68. 
'Ve ger ol ben Âl-i Selçükven derse ben hod Gök Alp oğluyın, derin. Ve ger bu vilâyete ben anlardan öndin geldüm derse, ben hod Süleyman Şah dedem hod andan evvel geldi"17 Görüleceği üzere burada Karacahisar'ın ele geçirilmesi ve ardından Anadolu Selçuklu Sultanı Alâeddin tarafından Osman Gazi'ya sancak gönderilmesi bağımsızlığın başlangıcı olarak gösterilir.

Zira Sultan Alâeddin, hâkimiyet alametlerini almak için her bakımdan uygun bir şahıstır. Ahmedî, İskendernâmesinde ideal gazi tipi olarak Sultan Alâeddin'i gösterdikten sonra Osmanlıları da Sultan Alâeddin'den sonraki gaziler olarak takdim eder.18 Nitekim Âşıkpaşazâde de Sultan Alâeddin'den sancak geldiğini ifade ettikten sonra, niçin nevbet vurulduğunu iki nedene bağlayarak açılar ve Osmanlıları bir gâzi topluluk olarak tanımlar: "Biri budur kim bunlar gâzilerdür. Nevber kim urulur, ilâm-ı gâzadur; "gazâya hazır olun" demek olur. Bunlar dahi "Allah rızâslyçün gazâya hazıruz" deyü ayağın dururlar. Ve bir dahi bunlar sâhib-i çırak, sâhib-i sofra ve sâhib-i alemdir. Ve sâhib-i simâtlardur kim âlem halkına ni'metler yidürürler. Nitekim Halîlürrahman'da ki bu âdetdür, ikindü vaktinde nevbet ururlar kim, halk gelüp ta'âmyiyeler."19 Bu anlamda ilk Osmanlı kroniklerinde Osmanlı padişahlarının vasfi olarak geçecek "gazi" sıfatını hakkıyla taşımış dahası bu işin "ideal tip"ini oluşturmuş bir sultandan hâkimiyet alametlerini almış olmak oldukça uygun olacaktır.

İlk kroniklerde yer alan Karacahisar'ın zaptının ardından Sultan Âlaeddin tarafından Osmanlılara bağımsızlık alametleri gönderildiği şeklindeki bilgi biraz farklı bir şekilde Vilâyetnâname-i Hacı Bektaş-ı Velî de geçer burada Anadolu Selçuklu Sultanı olarak Alaeddin Keyhüsrev geçer. Alaeddin Keyhüsrev, Germiyan, Aydın, Karesi, İsfendiyar ve Hızır beylerine hâkimiyetini kabul ettirmiş olmasına rağmen İnegöl, İznik, Bursa ve diğer birkaç önemli yer fethedilememiştir. Bursa'yı fethetmek için harekete geçmiş ve Sultanönü'ne vardığında Moğolların topraklarına saldırdığını öğrenince Sultanönünü önce Aydoğmuş’a verdi. Aydoğmuş ölünce kardeşi beyliği Sultan Alaeddin Keyhüsrev'den istemeye karar verdi. Ama öncelikle Hacı Bektaş-ı Veli'nin yanına uğrayarak onun duasını istedi. Hacı Bektaş-ı Veli, Erdoğdu için şu duayı yaptı: "[E]y büyük

\footnotetext{
17 Âșıkpaşazâde, Âşıkpaşazâde Tarihi, s. 28-29.

18 Ahmedî, İskendernâme, haz. Hasan Akçay, Harran Üniversitesi Sosyal Bilimler Enstitüsü Türk Dili ve Edebiyatı Anabilim Dalı, Eski Türk Edebiyatı Bilim Dalı Yayınlanmamış Yüksek Lisans Tezi, Urfa, 1999, s. 219-220.

19 Âșıkpaşazâde, Âşılkpaşazâde Tarihi, s. 17-18.
} 
Erdoğdu Alp’ım; yedi yıldır, saltanat, Selcük boyundan alındı. Rûm erenlerinin her biri bu seccadeye birini lâyı gördüler. Ben, senin ve evlâdının ruhlarını vilâyet kabzasında saklayıp durmadayım, yürü, zâhir padișahına var, gönlündekini söyle, gönlünde biz otururuz, dilinden biz söyleriz. Seni ona şirin gösteririz, kardeşinin sancağını alırsin; atın yürük, kllıcın keskin olsun, önünden, sonun gür olsun." Erdoğdu, Alaeddin Keyhüsrev'in huzuruna çıktı. Sultan kendisine sancağı verdi, kılıç kuşattı. Sırtını sıvazlayarak "kimse senin ve soyunun arkasını yere getiremesin" şeklinde dua etti. Sultan Alâeddin Keyhüsrev, Erdoğdu da vefat edince beyliği Gündüzalp’e verdi. Bu sırada Erdoğdu'nun oğlu Osman çok küçüktü. Büyüyüp beyliği idare edebilecek yaşa gelince beyliğin ileri gelenleri beyliğin Osman'ın hakkı olduğuna karar verdiler. Osman'ın Yarhisar, Bilecik, İnegöl, İznik gibi yerlere akınlar düzenlemesi üzerine Bursa tekfuru kendisini Alâeddin Keyhüsrev'e şikâyet etti. Alaeddin Keyhüsrev, Osman'ın derdest edilerek kendisine gönderilmesini istedi. Neticede Osman Alaeddin Keyhüsrev'in huzuruna çlktı. Sultan Alaeddin Keyhüsrev Osman'dan çok etkilenmesine rağmen onu Hacı Bektaş-ı Veli'ye göndererek görüşlerini öğrenmek istedi. Hacı Bektaş-ı Veli, Osman karşısında görünce ona kendisinin ve soyunun ikbali hakkında müjdeler verdi. Hacı Bektaş-ı Veli, Osman'a bir başlık giydirdi ve belindeki kemeri ona taktı ve şöyle söyledi: "bunları al... seni din düşmanlarına havale ettik. Senin başındaki tacımızı gören kâfirler, kılıcına karșı duramasınlar, kilıçları seni kesmesin, nereye varırsan üst gel, önünden sonun gür gelsin, kimse, senin soyunun sırtını yere getiremesin. Hünkâr adımı sana bağışladım, senin soyunun adını bu adla ansınlar. Gün doğusundan gün batısına dek çerağın yansın. Rûm erenleri bu makamı birine vermek istedi, her biri, bir eri tuttu. Bense yedi yıldır senin ve soyunun ruhların vilâyet kabzasında saklayıp durmadayım. İște geldin, nasibini aldın. Sonra padişah adamlarına varın, oğlumuz Sultan Alaeddin Padişah'a söyleyin, buna yüce bir makam versin, o da bizim gibi kâfirlere havale etsin bunu" dedi. Olanlardan haberdar edilen Alâeddin Keyhüsrev, Osman Bey'e Sultanönü'nü verdi ve hilat giydirdi. Ardından da altın sancak ve tablhane gönderdi.20 Saltukname adlı eserde de Sultan Alâeddin zamanından sonra ilahi olarak hâkimiyetin Osmanlılara verildiği iddia edilir. ${ }^{21}$

20 Menâkıb-ı Hacı Bektâş-ı Veli, Vilâyet-nâme, haz. Abdülbaki Gölpınarlı, İnkılap Kitabevi, İstanbul, 1958, s. XXV, 73-77.

21 Ebu Hayr-ı Rumî, Saltuk-nâme, II, haz. Ș. Haluk Akalın, İstanbul,1988, s. 46-47, 109$111,183-186$. 
Bazı erken dönem Osmanlı kroniklerinde Osmanlı Devleti'nin kuruluşunu müjdeleyen rüyayı gören kişi Osman Gazi, yorumlayan kişi de Anadolu Selçuklu Sultanı Alaaddin'in Veziri Abdülaziz olarak gösterilir. Bu anlamda devletin kuruluşu ile Anadolu Selçuklu Sultanı Alaeddin arasında bir bağ kurulur. ${ }^{22}$

Nitekim ilk kroniklerde aktarılan bu bilgi çok daha sonra tertip edilmiş bir münşeat mecmuasında Sultan Alâeddin'in Osman Bey'e gönderdiği iddia edilen fermanlara, mektuplara ve cevaben gönderilen mektuplara yer verilmiștir. ${ }^{23}$ Burada görüldüğü üzere Osmanlıların hâkimiyet hakkını Anadolu Selçuklularından aldığı ifade edilmeye çalışılmıştır. İlk Osmanlı kroniklerinde buna yönelik argümanlarla bu iddia delillendirilmeye çalışılmıştır. Ancak Osman Bey'e gönderildiği iddia edilen menşur ve fermanların sahte olduğu kanıtlanmıștır. ${ }^{24} \mathrm{Bu}$

22 Gürsoy Akça-Yunus İnce, Klasik Osmanlı Çağında Tarih, Meşruiyet ve Rüya, Palet Yayınları, Konya, 2015, s. 268.

23 Feridun Ahmed Bey, Mecmua-yı Münşeat-ı Feridun Bey, I, Takvimhane-yi Âmire, [İstanbul], 1265-1274, s. 48-65

${ }^{24}$ Friedrich von Kraelitz, Feridun Ahmed Bey'in münșeatı hakkında eserin içerdiği belgelere dair ilk değerlendirmeyi yapan kişidir. Kraelitz, Feridun Ahmed Bey'in münşeatındaki belgelerin özellikle Osmanlı Devleti'nin kuruluş evresine ait olanların dil özelliklerinin devrin dil yapısına uymadığını belirterek bu durumun Feridun Bey'in bu belgeleri defterhanelerden aldığı haliyle muhafaza etmek yerine kendi devrinin lisanına göre eserine aktardığı kanaatindedir. Kraelitz, Feridun Bey'in Türkçenin hakir görüldüğü bir dönemde yaşadığından ve kendisi de eserini padişaha sunmak istediğinden devrinde daha kabul edilebilir olan bir lisana göre belgelerin dilinde kısmî bir değişikliğe gitmiş olabileceğini ifade eder. Daha sonra Mükrimin Halil Yinanç Osmanlı devletinin ilk dönemlerine dair yazılan belgelerin Harzemșah Sultanı Alâeddin Tekiş zamanında divanda münşîlik yapan Muhammed b. Müeyyed elBağdâdî'nin et-Tevessül ile't-teressül adlı eserinde bulunan mektupların içerdiği kişi ve yer isimlerin değiştirilerek XVI. yüzyıl diline yapılmış çevirileri olduğu hakkında bazı deliller öne sürmüștür. Örneğin Osman Bey'e Söğüt ve havalisinin Anadolu Selçuklu Sultanı Alaeddin tarafından 683 (1284-1285) yılında Osman Bey’e verildiğini belirten temliknamenin gerçek olması mümkün değildir. Zira bu dönem zarfında Anadolu Selçuklu tahtında İzeddin Keykavus bulunmaktadır. Mükrimin Halil Yinanç, konuya tahsis ettiği bir dizi makalesinde ilk döneme dair münşeata alınmış belgelerin ayrıntılı bir değerlendirmesini yapar. Friedrich von Kraelitz, "ilk Osmanlı Padişahlarının Isdar Etmiş Oldukları Bazı Beratlar," Tarih-i Osmani Encümeni Mecmuası [TOEM], V/28, İstanbul, 1330 [1914], ss. 242-243; Mükrimin Halil [Yinanç], "Feridun Bey Münșeatı," Tarih-i Osmani Encümeni Mecmuası] [TOEM], XI-XIII/62-77, İstanbul, 1336-1339, ss. 161-168; Mükrimin Halil [Yinanç], "Feridun Bey Münșeatı," Tarih-i Osmani Encümeni Mecmuası] [TOEM], XIV/1, (78), İstanbul, 1340, s. 37-46; Mükrimin Halil [Yinanç], "Feridun Bey Münșeatı," Tarih-i Osmani Encümeni Mecmuası] [TOEM], XIV/2, (79), İstanbul 1340, ss. 95-104; Mükrimin Halil [Yinanç], "Feridun Bey Münşeatı," Tarih-i Osmani Encümeni Mecmuası] [TOEM], XIV/4, (81), İstanbul 1342, ss. 216-226. 
konuda yapılan bir araştırmanın gösterdiği üzere; Osman Bey'in Gazan Han zamanında Moğollara bağlanan bir bey olduğu anlaşılmaktadır. Dolayısıyla Anadolu Selçuklu Sultanı III. Alaedddin Keykubat'ın Osman Bey'e hâkimiyet alametleri göndermesi teknik olarak mümkün görünmemektedir. Erken dönem Osmanlı tarih yazıcılı̆̆ında Moğollar için üretilen kâfir, zalim, gaddar kavim imgesi Osmanlıların hâkimiyetin Moğollardan almış olmasını kabul edilebilir olmaktan çıkarmıştır. ${ }^{25}$

$\mathrm{Bu}$ konuda verilecek bir örnek, Osmanlıların hâkimiyet alametlerinin alınması hususunda Moğollara göre daha kabul edilebilir olduğunu düșündükleri Anadolu Selçuklu Devletini tercih etmelerinin gerekçesini daha anlaşılır kllacaktır. Şeyh Bedreddin, isyanında kendisine meșruiyet kazandırmak adına, soyunu muteber bir soya dayandırmaya çalıștığı anlaşılmaktadır. Nitekim Torunu Halil bin İsmail tarafından yazılan menakıbnamesinde Şeyh Bedreddin'in soyu Anadolu Selçuklu Sultanlarında III. Alâeddin Keykubad'da (12931307) çlkarılır. ${ }^{26}$ Böylece Şeyh Bedreddin'in soyu, Anadolu'nun Osmanlılar öncesi sahiplerinde temellendirilerek isyanına/egemenlik iddiasına haklılık kazandırılmaya çalışılmıştır. Buradan şu sonuç ortaya çıkmaktadır. Şeyh Bedreddin'in isyan ettiği sırada Anadolu'daki Türkler arasında muteber olan soy asaleti Moğollar'dan ziyade Anadolu Selçukluluları'nındır.

Esasen sayısı çok olmamakla birlikte bazı Osmanlı kroniklerinde Moğol istilasından sonra Anadolu'da Anadolu Selçuklularının sadece adının kaldığından bahsedilmektedir. "Çünki Tatar Rûm'a hâkim oldı, mülûk-i Selâçıka'nun heman bir adı kaldl."27"Bu sıralarda, Selçukluların Tatarlarla savaşmaları mümkün değildi. Zira I. Alaeddin'in ölümünden sonra Tatarlar Anadolu'yu istila ettiklerinden Selçuklular onların elinde esir gibiydiler"28 İlk dönem kroniklerinde zikredilen Osman Bey'in Anadolu Selçuklu Hükümdarı

\footnotetext{
25 Baki Tezcan, "Erken Osmanlı Tarih Yazımında Moğol Hatıraları", Osmanlı Sarayında Tarih Yazımı, çev. Zeynep Nevin Yelçe, ed. H. Erdem Çıpa-Emine Fetvacı, Tarih Vakfı Yurt Yayınları, İstanbul, 2014, ss. 27-45; İlk dönem kroniklerindeki olumsuz Moğol imgesi için bakınız. Yunus İnce, "'Klasik Dönem Osmanlı Tarih Yazımında Moğol İmgesi", Köktürk Yazısının Okunușunun 125. Yllında Orhun'dan Anadolu'ya Uluslararası Türkoloji Sempozyumu 1-7 Haziran 2018 Ulanbator-Moğolistan, Bildiriler Kitabı, II, Kesit Yayınları, İstanbul, 2018, ss. 926-940.

${ }^{26}$ Hali b. İsmail, Simavna Kadısığlu Șeyh Bedreddin ve Menâkıbı, haz. Abdülbaki Gölpınarl, Milenyum Yayıncılık, İstanbul, 2008, s. 237-238.

27 Mevlâna Mehmed Neşrî, Cihânnümâ [Osmanlı Tarihi (1288-1485)], (Kısaltma: Cihannüma), haz. Necdet Öztürk, , İstanbul, Çamlıca Basın Yayım, İstanbul, 2008, s. 36. 28 Müneccimbașı Ahmed b. Lütfullah, Camiü'd-Düvel, s. 74.
} 
Sultan Alâeddin'den hâkimiyet alametlerini aldığı bilgisi gerçeği yansitmamaktadır. $\mathrm{Bu}$ anlamda bu konuda aktarılan bilgilerde gerçeğin gizlenmesi ve çarpıtma söz konusudur.

İlk dönem Osmanlı kroniklerinde üstü örtülen ve çarpıtılan bir diğer hadise Osman Bey'in amcası Dündar Bey'i öldürmesi meselesidir.

\section{II- Osman Bey'in Amcası Dündar Bey'i Öldürmesi}

Osmanlı Devletinde hanedan üyelerinin öldürülmesine yönelik uygulamanın Fatih Sultan Mehmed'in meşhur kânûnnâmesi ile başladığı düşünülse de esasen bu uygulamanın başlangıcı neredeyse devletin kuruluş devrine kadar geriye gider. ${ }^{29}$

Erken dönem Osmanlı kronik yazarlarından Mehmed Neşrî, Osmanlı Devletinin kurucusu Osman Bey ile amcası Dündar Bey arasında yaşanan bir saltanat mücadelesine yer verir. Mücadelenin kazananı Osman Bey, beyliğe sahip olurken, Dündar Bey hem beylikten hem de canından olur. Neşrî bu durumu şe şekilde aktarır: "Itttifâk ol esnâda Er-tugrul Beg toksan üç yaşında âhirete intikâl idüp, Sögüd'de defn ittiler. Göçer-evler ba'zı Osmân'ı ve ba'zı Er-tugrul[uñ] kardaşı, Osman'uñ ammusı Tundar'ı beg kılmak istediler. Ammâ, kendü kâbilesi Osmân'ı vech görüp, el altından haber gönderüp, halk ortasina gelicek, Tundar, halkınuñ Osmân'a meyl ve inkıyâdın görüp beglikden vaz gelüp, Osmân'a teba'at itdi"30 Osman Bey, bu hadiseden sonra amcası Dündar Bey'i kendisine kethüda tayin etmiştir. Daha sonra Bilecik tekfuru ile Köprühisar tekfuru arasında meydana gelen anlaşmazlıkta Osmanlılar, Bilecik tekfurunun tarafını tutmuştur. Köprühisar üzerine yürüyen Osmanlılar tekfuru yenerek topraklarını ele geçirmişlerdir. Sonrasında Bilecik tekfurunun verdiği bir ziyafette böbürlenmesini içine sindiremeyen Osman Bey, tekfur üzerine gitmek isteyince Dündar Bey, Osman Bey'in bu kararını onaylamadığını beyan edip karşı çıkınca, Osman Bey okla vurarak amcasını öldürmüştür. Neşrî tarihinde bu hadise şu şekilde hikâye edilmiştir: "Osmân, Bilecik tekfurınuñ beglenüp, kendünüñ elin öpdürdügine incinüp, diledi ki, hemândem kavrayup tekfuru tuta. Ammusı Tundar'ıla müşâveret idüp,

\footnotetext{
29 "Bu kânûnnâme atam ve dedem kânunudur ve benim dahi kânunumdur. Evlâd-ı kiramım neslen ba'de neslin bununla âmil olalar... Ve her kimesneye evlâdumdan saltanat müyesser ola, karındaşların nizâmı âlem içün katl itmek münâsibdür. Ekser-î ulemâ dahi tecvîz itmișdür. Anunla âmil olalar" Fatih Sultan Mehmed, Kanûnnâme-i Âli Osman (Tahlil ve Karşılaştırmalı Metin), haz. Abdülkadir Özcan, Kitabevi Yayınları, İstanbul, 2007, s. 3, 18.

30 Mevlânâ Mehmed Neșrî, Cihânnümâ, s. 39.
} 
Tundar eyitdi: 'Öte tarafta Germiyan-oglı adû, etrâfun kâfirleri bize düssmen, bunı dahı düssmen idicek bize dahı turıcak yir kalmaz. Ve Dündar'uñ bu sözi Osmân'a güç gelüp, kendünün hurûcına men añ layup, okıla Dündar'ı öldürdi."”1

Âşıkpaşazâde Tarihinde Osman Gazi'nin Bilecik tekfurunu cezalandırma isteğine engel olan amcası Dündar'ı okla vurmasına hiçbir şekilde değinilmediği hatta Osman Gazi'nin Bilecik tekfuru ile dostluğunu muhafaza etmeye çalıştı̆̆ ifade edilmektedir: "Osman Gâzi eydür: ..."Evvel rây u tedbîr budur kim konşularımuz ile müdârâ dostlukların edevüz." Nitekim Bilecik teküriylen dâyima dostluk ederlerdi. Yaylaya gitseler emânetlerini dahi Bilecik hisarında korlarıdı. Gelseler tulum ile peynirler, karınile kaymak katıkları, eyü halılar ve kilimler göndürürleridi. Amma er kişiyle göndürmezleridi. Hatun kişiler ile göndürürleridi. Anlar dahi Osmân Gâzi'ye gâyetde i'timâd ederleridi...Osmân Gâzi, Bilecik kâfirlerine gâyetde hürmet ederdi. Sordular kim: 'Bu Bilecik kâfirlerinin nice hürmeti var senün yanında derler. "Eyitdi kim: "Komşularımuzdur. Biz bu vilâyete garib geldük. Bunlar bizi hoș tuttular. İmdi bize dahi vâcibdür kim bunlara hürmet edevüz" dedi.

Vâcibdür dostluknetmek konşuyilen/Sakın kim konşuyu olmaya yılan

Kime kim dostluk etsen et hazer sen/Hazersüzdür başı yollarda kalan

Hassâ kim kâfir olsa dost edinmez/Dilinde dini bâtıl, kavli yalan"32 Âşıkpaşazâde'nin bu satırlarında gerçeğin görmezden gelinmesi ve üzerinin örtülmesi durumu söz konusudur. İlk dönemin bir diğer kronik yazarı Oruç Bey'in kardeş katli hakkında sarf ettiği şu sözler tam anlamıla bir sansür niteliğindedir: "Ve ol zamânda olan pâdişâhlar ve begler ve beg oglanları uluca kardaşlarıyla bilece tanışı iderlerdi. Birbirlerine hürmet ederlerdi. Birbirlerini öldürmezlerdi, tâ Yıldırım Hân Bayezîd zamânına dek kardaş kardaşı öldürmek yogıdı. Yıldırım Hân zamânında oldı." 33 Oruç Bey, Osman Bey'in daha beylik kuruluş aşamasındayken amcası Dündar'ı öldürmek suretiyle başlattığı hanedan üyelerinin öldürülmesini/kardeş katli meselesini görmezlikten gelme eğilimindedir.

31 Mevlânâ Mehmed Neșrî, Cihânnümâ, s. 45.

32 Âşıkpazşazade, Așsıpaşazade Tarihi, s. 18-19, 22.

33 Oruç Beğ, Oruç Beğ Tarihi [Osmanlı Tarihi -1288-1502], haz. Necdet Öztürk, Çamlıca Basın Yayım, İstanbul 2008, s.18. Benzer ifadeler için bakınız. Anonim Tevârîh-i Âl-i Osman, haz. F. Gise, çev. Nihat Azamat, Marmara Üniversitesi Yayınları, İstanbul, 1992, s. 16-17. 
Görüleceği üzere burada bir hanedan üyesinin şahsî iktidar alanı için bir muhalefet odağı olarak gördüğü bir başka hanedan mensubunu öldürmesi durumu söz konusudur. Bu anlamda iktidara sahip olmak için bir hanedan üyesinin öldürülmesi hadisesinin geçmişi devletin kuruluşuna/ kurucusuna kadar gitmektedir.

Elbette ki bu noktada şu soru sorulmalıdır. İlk Osmanlı kronikleri niçin bu hadiseden bahsetmezler? Öncelikle yukarıda da değinildiği üzere ilk dönem kroniklerinde Osmanlıların gâzi kimliklerine özellikle vurgu yapıldığı görülür. Daha devletin başında iki hanedan üyesinden birisinin şahsî iktidarına rakip olarak görmesi nedeniyle bir diğer hanedan üyesini öldürmesi hanedan için seçilen imaja zarar verir niteliktedir.

Gerçeğin üzerinin örtülmesi ile ilgili ilk kroniklerde geçen bir diğer olay Timurlu Hükümdarı Şahruh tarafından gönderilen hilatların II. Murad tarafından giyilmesi meselesidir.

\section{III-II. Murad'ın Şahruh'un Gönderdiği Hilatı Giymesi ya da Timurlular'a Bağlılık}

Osmanlı Devleti'nin askerî ve siyasi potansiyeli ve meşruiyet dayanakları, Timurluların askerî, siyasi varlıklarını ve egemenlik hakkı iddialarını dengeleyebilecek nitelikteydi. Dolayısıyla Timurlular için Osmanlılar, hem somut güç hem de ideolojik bakımdan baskılanması, kontrol altına alınması gereken bir güçtü. Öyle olduğu için Timurlular, Osmanlılara toplumsal ve siyasal baskı uygulamışlardır. Onların baskı siyaseti Osmanlılarla da sınırlı kalmamıştır. Timur'un oğlu Şahruh, 1435 yılında, II. Murad'a ve yine onunla beraber Karamanoğlu İbrahim Beğ'e Dulkadiroğullarından Emir Nâsırüddin Muhammed b. Dulkadir'e, Karayülük evladına hilatlar göndermiștir. ${ }^{34}$ Hâkimiyet bakımından üstünlüğün sembolü olan hilatları II. Murad'ın, Karamanoğlu İbrahim Bey'in, Karayülük'ün oğlunun ve Dulkadiroğlu Emir Nâsırüddin'in giydiği bilinmektedir. 35

II. Mehmed devrinde Osmanlı ordusunda bir yeniçeri olan Konstantin Mihailović, II. Murad'ın Timur Devleti'ne yıllık 100.000 düka vergi vermeyi kabul ettiğini, daha sonra bu verginin keçeden yapılmış 1000 kışlık, 1000 de yazlık at örtüsüne dönüştürüldüğünü

\footnotetext{
34 “Bu ayda İkhan Şahruh, Melik-i Rûm Murad b. Osman'a, Sarimuddin İbrahim b. Karaman'a Karayülük ve evladına ve [Emir] Nâsırüddin Muhammed b. Dulgâdir'e hilatlar gönderdi." Makrızî, Kitâbu's-Sülûk li Ma'rifeti Düveli'l-Mülûk, IV, 2. bölüm, haz. Said Abdulfettah Aşur, Mısır Ulusal Kütüphanesi Yayınları, Kahire, 1972, s. 957.

35 Tagrîberdî, en-Nücûmu'z-Zâhire fî Mülûk Mısır ve'l-Kâhire, XIV, Dâru'lKütübi'lillmiyye, Beyrut, 1992, s. 248.
} 
ifade etmektedir. Mihailović, hatıratında kaydettiği bu bilgileri muhtemelen duymuştur. Nitekim aktardıklarını teyit eden başka bir kayıt yoktur. Üstelik kayıtlarında bilgi yanlışlıkları bulunmaktadır. Örneğin, Yıldırım Bayezid'i II. Murad'ın babası olarak kaydetmiștir. 0 dönemde Timur Devleti'nin başında da Timur'un olduğunu yazmaktadır. ${ }^{36}$ Dolayısıyla verginin II. Murad tarafından Timur'a verildiği gibi bir durum ortaya çıkmaktadır. Oysa II. Murad döneminde Timur Devleti'nin başında Şahruh bulunmaktaydı. Böyle olmakla birlikte onun kaydettiği bilgilerden II. Murad zamanında Osmanlıların Şahruh'tan çekindiğini ve bu çekinmenin bir yeniçeri tarafından bilinecek kadar yaygın olduğunu çıkarmak mümkündür.

Buna rağmen bu bilgiler Osmanlı kroniklerinde geçmez. Bu bilgilere ancak Memlüklüler coğrafyasında yaşayan iki müverrihin eserinde rastlanılmaktadır. Zira bu bilgi, cihanşumül bir egemenlik iddiasında olan bir devletin, bir başka devletten çekindiği, hatta o devletin egemenliğini kabul ettiğini ifade etmektedir.

Devrin kroniklerinde görmezden gelinen bir diğer hadise Fatih Sultan Mehmed'in oğlunun ölümü ve Veziriazam Mahmud Paşa'nın öldürülmesi arasındaki ilişkidir.

\section{Ölümü}

IV-Fatih Sultan Mehmed'in Oğlu Şehzade Mustafa'nın

Fatih Sultan Mehmed'in Cem ve Bayezid dişında Mustafa adlı bir oğlu daha vardır. Şehzade Mustafa'nın aniden ölümü ile Veziriazam Mahmud Paşa'nın idamı arasında bir bağlantı olduğu anlaşılmaktadır. Ancak bahsi geçen bağlantıya birçok kronik yazarı ya hiç değinmez ya da üstü örtülü bir şekilde anlatmayı tercih eder. Âşıkpaşazade, Oruç Beğ, Mehmed Neşrî, ya da yazarı belirsiz bazı anonim ${ }^{37}$ eserlerdeki gibi Osmanlı tarihçileri bu konuya eserlerinde hiç değinmeyip

\footnotetext{
36 Konstantin Mihailović, Bir Yeniçerinin Hatıratı, çev.- haz. Kemal Beydilli, Tarih ve Tabiat Vakfı Yayınları, İstanbul, 2003, s. 39. Timur'a dair verilen bilgiler için bk. 3639.

37 Anonim Kitâb-ı Tevârih-i Âl-i Osmân, haz. Vehbi Günay, Ege Üniversitesi Edebiyat Fakültesi Yayınları, İzmir, 2011, s. 137-139; Anonim Osmanlı Kroniği (1299-1512), haz. Necdet Öztürk, Türk Dünyası Araştırmaları Vakfı Yayınları, İstanbul, 2000, s. 129; Anonim Tevârih-i Âl-i Osman, haz. Ahmet Akgün, Marmara Üniversitesi Sosyal Bilimler Enstitüsü Tarih Bölümü Yayınlanmamıș Yüksek Lisans Tezi, İstanbul, 1988, s. 56; Anonim Tevârîh-i Âl-i Osmân, haz. Ali Birbiçer, Marmara Üniversitesi Sosyal Bilimler Enstitüsü Yayınlanmamıș Yüksek Lisans Tezi, İstanbul, 1989, s.146.
} 
görmezden gelirlerken, İbn Kemal,38 İdris-i Bitlisî,,39Müneccimbașı Ahmed b. Lütfullah, ${ }^{40}$ Hoca Sadeddin Efendi, ${ }^{41}$ Solakzâde Mehmed Hemdemî, ${ }^{42}$ gibi kronik yazarları Şehzade Mustafa ile Mahmud Paşa arasında kökeni eskiye dayanan bir anlaşmazlık olduğunu, Şehzade Mustafa'nın ölümünü müteakip Mahmud Paşa'nın Edirne'deki ikametgâhından matem elbiseleri içerisinde Fatih Sultan Mehmed'e taziyeye gittiğini ancak paşanın düşmanlarının kışkırtmaları neticesinde Mahmud Paşa'nın önce zindana atıldığını, sonra da idam edildiğini ifade ederler. Ancak bahsi geçen kronik yazarları bu anlaşmazlı̆̆ın kökenine ve nedenine dair bilgi vermezler. $\mathrm{Bu}$ mevzunun ayrıntısına dair Gelibolulu Mustafa Âlî̀nin Künhü'l-Ahbâr adlı eseri ile Muâli'nin Hünkârnâmesindeki bilgiler incelendiğinde meselenin basit bir anlaşmazlıktan öte olduğu görülür. Hatta bu mesele en nihayetinde Mahmud Paşa'nın da idamına neden olur. Olayın ayrıntılarına dair Gelibolulu Mustafa Âlî’nin, Muâli'nin yazdıkları ile Şehzade Mustafa'nın kâtibi Giovan Maria Angiolello'nun ve Teodoros Spandunis'in verdiği bilgiler mevzunun anlaşılması açısından oldukça önemlidir. Giovan Maria Angiolello, Şehzade Mustafa'nın ölümünün ardından Mahmud Paşa'nın önce hapsedilmesi ardından da idamı arasında bir bağ kurar. Mahmud Paşa'nın öldürülmesi hususunda birçok rivayet dolaşmaktadır. Uzun Hasan ile mücadele sırasında Mahmud Paşa'nın Fırat Nehrini geçmemesi yolundaki uyarılarına rağmen öncü kuvvetlerin kumandanı Has Murad Paşa nehri geçince Akkoyunlu askerleriyle karşılaşır ve Osmanlı öncü kuvvetleri yenilir. Has Murad Paşa da Fırat Nehrinde boğulur. Bu olay Mahmud Paşa'nın Has Murad Paşa'ya yardım etmemesi neticesinde meydana gelen bir felaket olarak anlaşllır. Angiolello, Şehzade Mustafa Karaman Beylerbeyi iken, Develi şehrini almak için uğraşırken hastalandığını, şehri teslim almak için Develi'ye giden şehzadenin dönüşte Bor'da bir kaplıcanın suyuna girdiğini ve kaplıcadan çıkışta vefat ettiğini ifade eder. Yine Angiolello, Mahmud Paşa'nın öldürülmesi hususunda etrafta dolaşan dedikoduları aktarır: "Anlaşıldığı kadarıyla Büyük Türk Beyi [Fatih Sultan Mehmed], arkadaş olmadıkları için Has Murad'a yardım etmediğinden dolayı Mahmud'u

\footnotetext{
38 İbn Kemâl, Tevârih-i Âl-i Osman VII. Defter, haz. Șerafettin Turan, Türk Tarih Kurumu Yayınları, Ankara, 1991, s. 373-377.

39 İdris-i Bitlisî, Heșt Behişt VII. Ketibe Fatih Sultan Mehmed Devri, haz. Muhammed İbrahim Yıldırım, Türk Tarih Kurumu Yayınları, Ankara, 2013, s. 233-234.

40 Müneccimbaşı Ahmed b. Lütfullah, Camiü'd-Düvel, s. 287-288.

41 Hoca Sadeddîn Efendi, Tâcü't-Tevârîh, I, İstanbul, 1279-1280, s. 552.

42 Solakzâde Mehmed Hemdemî, Solakzâde Tarihi, İstanbul, 1297/1298, s. 250-251.
} 
cezalandırmıştı. Türk Beyi de Mahmud'a askerleri tarafindan çok sevilen ve yetki sahibi biri olduğu için güvenmiyordu. Bazıları da Mahmud'un, Türk Beyinin oğlu Mustafa'ya zehirli bir armut verdiği ve tam Uzun Hasan ile Mustafa arasında olan savaș sırasında acıktığı için bu armudu yediği ve ölümüne sebep olan o uzun hastalığa yakalandığını söylemektedirler. Ben Zuan Maria bunun yalan olduğunu söyleyebilirim. Çünkü o zamanlar Mustafa Bey'in emrindeydim ve evinde bulunuyordum. Babası onu beklerken ve daha önce söylenen altın fincanda ona șerbet sunarken gördüm ve yaşadım. Yani Türk Beyi'nin Mahmud Pașa'yı öldürtme sebebi, her ne kadar Has Murad'a yardım etmemiş olması ve yenilgi için gibi gösterilmek istense de, aslında kıskançllk olmuştur. Zehirli armut hikâyesi doğru değildir. Çünkü Mustafa savaștan döndüğünde üç ay sağlıklı bir șekilde yașamıș ve sonra hastalanıp, altı ay sonra da, ileride göreceğiniz gibi ölmüștür." Sehzade Mustafa'nın ölümünden sonra iç organları çıkartılarak, yerine buğday doldurulup, balla tahnit edilmiş, katranla kaplı bir tabuta konularak önce Konya'ya ardından da İstanbul'a tașınmıștır. Nihayetinde de Bursa'da toprağa verilmiștir.43 Angiello da Şehzade Mustafa ile Mahmud Paşa'nın arasının neden açık olduğuna değinmez.

$\mathrm{Bu}$ konuda bilgi veren iki Osmanl kroniği mevcuttur. Gelibolulu Mustafa Âlî, Künhü'l- Ahbâr adlı eserinde şehzade ile paşa arasındaki düşmanlığın kökenine ve nedenine açıklık getirir: " $F e$ emmâ hikmet-i Hüdâ'nundur, Şehzâde Sultân Mustafa Han'la mâbeynlerinde bir vahşet hâdis oldu. Ol hâlete, müşîr-i müşârünileyhün haremine müte'allik bir gayr-i vâkî töhmet bâ'is oldr. Pes muhâlefet ü udvân mâbeynlerinde izyâd ile nümâyan iken, șehzâde-i mesfûr bagtet vefât eyledi. Ba'zı müfsîdin "Mahmud Paşa zarâfetle zehr içürdi" diyü vahșet-i kadîmeye binâen müdde'âsını zu'mınca isbât eyledi. Bu fitne'i kübrâ vezîr-i mezbûrun dahi katline kâr-sâz-ı hafi olub"44 Burada Şehzade Mustafa'nın Mahmud Paşa'nın eșlerinden birisi arasındaki gayri meșru bir ilișkiden/namus meselesinden bahsedilmektedir. Bu konu hakkında bilgi veren bir diğer kaynak olan Mu'âli'nin Hünkârnâmesinde Şehzade Mustafa'nın ağzından lalasına hitap eder tarzda, bir konuşma nakledilir. Burada şehzade ölümünden Mahmud Pașa'nın sorumlu olacağı ifade etmektedir: "Benim lalam, beni dinle. Benim bu son sözlerim kulağında kalsın; ben öleceğim, Mahmud yaşayacak ve hünkârın hizmetinde kalacak; benim gibi dünya

43 Giovan Maria Angiolello, Fatih Sultan Mehmed, çev. Pınar Gökpar, Profil Yayıncılık, İstanbul, 2011, s. 72-79.

44 Gelibolulu Mustafa Âlî, Künhü'l- Ahbâr, II, Fatih Sultan Mehmed Devri-1451-1481, haz. M. Hüdai Șentürk, Türk Tarih Kurumu Yayınları, Ankara, 2003, s. 182-183. 
nimetinden ve ana baba yüzlerini görmek saadetinden mahrum kalsın; babam Padişah olduğu müddetçe ondan bütün dünya nimetlerini selb etsin; babamdan en son istirhamım şudur: Benim uğradığım bu felâketi Mahmud'dan sorsun; o bana düşmanlığı yüzünden bu fenalığı yaptı. Bu hakikat size malûm olsun." Burada açlktan bir itham söz konusudur. Şehzadenin vefatından sonra padişaha taziyeye giden Mahmud Paşa'nın "Mustafa öldü ise (memleket hizmetinde) ben varım" șeklinde sarf ettiği sözler ile hapse atıldığında sarf ettiği "senin isminin yanında halk arasında benim adım da zikrediliyor, eğer günahım büyükse merdce öldür, değilse beni serbest bırak" şeklindeki sözleri sonunu hazırlamıştır. ${ }^{45}$

Konu hakkında bilgi veren kaynakların karşılaştırmalı okumasının yapılması neticesinde yapılan modern araştırmalar, Şehzade Mustafa'nın ölümü ile Mahmud Paşa'nın öldürülmesi arasındaki eski husumetin rolünün olduğu, bu husumetin de bir namus meselesinden kaynaklandığı, ancak bu konudan bahseden Osmanlı kroniklerinin hadiseyi daha sterilize ederek aktarmayı tercih ettikleri anlaşılmaktadır. Özellikle İsmail Hakkı Uzunçarşılı'nın Topkapı Sarayında tespit ettiği II. Bayezid devrine dair bir belgede bu konuyu aydınlığa kavuşturacak çok önemli bilgiler bulunmaktadır. Söz konusu belgede Mahmud Paşa'nın idamından sonra çocukları, mahkemeye başvurarak, kendi hakları olan mirasın verilmesini talep etmişlerdir. Buna göre; paşanın sonraki eşinden olan çocukları, paşanın Şehzade Mustafa ile anlaşmazlığa düşmesine neden olan eşi ile bir kan bağlarının olmadığını ifade etmişler ve babalarının malından kendileri için miras olarak tahsis ettiği haklarını talep etmişlerdir. Burada aktarılanlara göre; Mahmud Paşa Eğriboz Seferine çıkmazdan önce mal varlığının bir kısmını evlatlarının tasarruf edebileceği bir vakfa dönüştürmüştür. Mahmud Paşa'nın evlatlarının ifadelerine göre; paşanın şehzade ile aralarının açılmasına neden olan diğer eşi, paşa seferde iken şehzadenin annesinin evine giderek geceyi orada geçirmiştir. Mahmud Paşa sefer dönüşü hadiseyi öğrenmiş ve çok üzülmüş ve karısını üç talakla boşamıştır. Devrin defterdarı olan kayınbiraderinin ısrarı ve padişahın zoruyla tekrar nikâhına alsa da veziriazamlıktan azledildikten sonra ikamet ettiği Hasköy’e bu eşini

\footnotetext{
45 İsmail Hakkı Uzunçarşıll, "Fatih Sultan Mehmed'in Vezîri Âzamlarından Mahmud Paşa ile Şehzade Mustafa'nın Arası Neden Açılmıștı", (Kısaltma: Mahmud Paşa ile Şehzade Mustafa), Belleten, XXVIII/112, Ankara, 1964, s. 722-723; Robert Anhegger, "Fatih Devrinde Yazılmış Farsça Manzum Bir Eser, Mu'âli'nin Hünkârnâmesi", Tarih Dergisi, I, İstanbul, 1949-1950, ss. 145-166.
} 
getirtmemiş ve özellikle Edirne'de bırakmıştır. Tüm bu hadiselere Veziriazam İshak Paşa da şahit olmuştur. ${ }^{46}$

Görüleceği üzere Uzunçarşılı'nın neşrettiği belge Şehzade Mustafa'nın Mahmud Paşa'nın eşine yönelik hareketini bir söylenti olmaktan çıkarmaktadır. Bu konuda Theodoros Spandunis'in verdiği bilgi de oldukça önemlidir. Her ne kadar Theodoros Spandunis eserini 1538 yılında tamamlamış olsa da Fatih Sultan Mehmed'in üvey annesi Mara, Spandunis'in halasıdır ve Spandunis bir dönem halasının yanında yaşamıştır. Yine Hersekzade Ahmed Paşa ve Mesih Paşa gibi Fatih Sultan Mehmed döneminin devşirme kökenli devlet adamları Theodoros Spandunis'in akrabası konumundadır. Tüm bu nedenlerden dolayı Theodoros Spandunis'in konu hakkında naklettiği bilgiler konumuz açısından oldukça önemlidir. Spandunis, bu mevzudan bahsederken yanlışlıkla Mahmud Paşa yerine Gedik Ahmed Paşa'nın ismini zikreder: "Bu adam [Mahmud Paşa] yukarıda değindiğimiz gibi sultanın Leonardo Tocco'yu ele geçirmek üzere gönderdiği, Otranto şehrini alan kişsiydi. Güzel bir karısı vardı. Mehmed'in oğlu Mustafa Çelebi bir sabah babasının elini öpmeğe gittiğinde Gedik'in karısını görüp ona âşık oldu. Bir öğle sonrasında kadınlar hamamına zorla girdi. Korumalardan hiç biri şehzadenin yolunu kesmeye cüret edemedi. Kadını çıplak gören şehzade onun ırzına geçti. Bunu öğrenen Gedik Ahmed [Mahmud Paşa] doğruca Mehmed'in yanına gidip işlenen suç için adalet istedi. Mehmed ona neden böyle yaygara kopardığını sordu. Gedik, sultanın ve böylece oğlunun kulu değil miydi? Eğer Mustafa bu eylemi yapmışsa, bunu kölesine yapmış demekti. Yine de Mustafa'yı kendi dairesine hapsetti. Üç ay sonra da boğdurdu. Ama genellikle Mustafa'nın hummadan öldügüne inanılmaktadır." 47 Gelibolulu Mustafa Âli'nin, Mûali'nin ve Theodoros Spandunis'in naklettiği bilgiler ile İsmail Hakkı Uzunçarşılı'nın neşrettiği belge dikkate alındığında Şehzade Mustafa'nın Mahmud Paşa'nın eşi arasında meydana geldiği iddia edilen hadiselerin ilk dönem kronikleri tarafından görmezden gelindiği anlaşılmaktadır. Burada şehzade ile paşanın eşi arasındaki münasebetin gerçek olup olmadığından ziyade, ilk kroniklerde bu konunun bahis mevzuu dahi

46 Uzunçarşıll, Mahmud Paşa ile Şehzade Mustafa, ss. 719-728; İsmail Hakkı Uzunçarşıll, "Osmanlı Tarihinde Gizli Kalmış veya Şüphe ile Örtülü Bazı Olaylar", Belleten, XLI/163, Ankara, 1977, ss. 510-513; Theoharis Stavrides, The Sultan of Vezirs, The Life and Times of the Ottoman Grand Vezir Mahmud Pasha Angelović (14531474), Brill, Leiden-Boston-Köln, 2001,s. 341-352.

47 Theodoros Spandunis, Osmanlı Sultanları, haz. Donald M. Nicol, çev. Necdet Balta, Kitap Yayınevi, İstanbul, 2015, s. 85-86. 
yapılmaması ya da üstü örtülü bir şekilde bahsedilmesi ilginçtir. $\mathrm{Bu}$ noktada şu akla gelebilir kronik yazarları böylesi mahrem bir mevzudan haberdar olmamış olmaları da bir ihtimal dâhilinde değil midir? Fatih Sultan Mehmed dönemi kronik yazarlarından Enverî, ${ }^{48}$ Şükrullah49 eserlerini Mahmud Paşa'ya ithaf etmişlerdir. Tursun Bey, on iki yıl Mahmud Paşa'nın hizmetinde bulunmuştur.50 Karamanî Mehmed Paşa da Mahmud Paşa'nın himayesinde yetişmiş, paşanın müşavirliğini yapmış ve teşvikini görmüştür. ${ }^{1}$ Yani devrin birçok kronik yazarının eserini yazmasında Mahmud Paşa'nın doğrudan ya da dolaylı olarak etkisi bulunmaktadır. Her ne kadar bahsi geçen kronik yazarlarının eserlerinin bir kısmı paşanın ölümüne kadar gelmese de paşanın himayesinde kronik yazarlarının da olduğu anlaşılmaktadır. Dolayısıyla burada haberdar olmamaktan ziyade duymama ya da görmezden gelme durumu söz konusudur.

Burada son olarak Fatih Sultan Mehmed devrinde yapılan iki sefer hakkında devrin kronik yazarı Tursun Bey'in verdiği bilgiler ele alınacaktır.

\section{V-II. Mehmed'in Belgrad ve Rodos Seferleri}

II. Mehmed, İstanbul'u aldıktan sonra kendisi kayzer/imparator olarak anılmış ve siyasi yapı da imparatorluğa evirilmiştir. Nitekim onun bu başarısı daha önce defalarca denenmiş ancak başarılamamış 52 bir ideale işaret etmektedir. Bu başarısından ötürü II. Mehmed, kendisinden sonra gelen şahıslar tarafından fâtih, imparator ve dâhi gibi sıfatlarıyla anılmıştır. II. Mehmed için bu unvanlardan en çok fâtih (fetheden) unvanın kullanıldığı görülür. Ancak Fatih Sultan Mehmed yaptığ tüm seferlerden zaferler elde ederek çıkmamıştır. II. Mehmed devrini yazan Tursun Bey'in eserinde

\footnotetext{
48 Enverî, Düsturnâme-i Enverî (Dil Özellikleri-Metin), haz. Betül Ademli, Sakarya Üniversitesi Sosyal Bilimler Enstitüsü Türk Dili ve Edebiyatı Anabilim Dalı Yeni Türk Edebiyatı Bilim Dalı, Yayınlanmamış Yüksek Lisans Tezi, Sakarya, 2007, s.73.

49 Şükrullah, Behcetü't-Tevârîh/Tarihin Aydınlı̆̆ında, haz. Hasan Almaz, Mostar Yayınları, İstanbul, 2013, s. 70-71.

50 Tursun Bey, Târîh-i Ebu'l-Feth, (Kısaltma: Târîh-i Ebu'l-Feth), haz. Mertol Tulum, İstanbul Fetih Cemiyeti Yayınları, İstanbul, 1977, s. 24.

${ }^{51}$ Karamanlı Nişancı Mehmed Paşa, "Osmanlı Sultanları Tarihi”, çev. İbrahim Hakkı Konyalı, Osmanlı Tarihleri, haz. H. Nihal Atsız, Türkiye Yayınevi, İstanbul, 1949, s. 323, 339.

$52 \mathrm{Bu}$ konuda bakınız. Byzantion'dan Constantinopolis'e İstanbul Kuşatmaları, ed. Murat Arslan-Turhan Kaçar, İstanbul Araştırmaları Enstitüsü Yayınları, İstanbul, 2017.
} 
Belgrad ve Rodos seferleri başarısızlıkla sonuçlanmasına rağmen, bir başarı hikâyesi gibi aktarılır.

Modern zamanlar öncesinde tarih denilince siyasi tarih, siyasi tarih denilince de savaşlar akla gelmektedir. Dolayısıyla tarih içerisinde başarıya ulaşmış seferler olduğu kadar başarısız olmuş seferler de olması gayet normaldir ve Osmanlı tarihinde de birçok bașarısız sefer vardır. Ancak belki de bu seferler içerisinde en anlatılası olmayanı İstanbul Fâtih'inin görece daha az önemli gibi gözüken iki kaleyi fethedememesini yazmak olmalıdır. II. Mehmed'in bașarısı öyle etkili olmuștur ki; tarih kendisini bu bașarısından sonra isminden ziyade bu unvanı (fâtih) ile anmıştır. Üstelik de böylesi bir hükümdarın tarihini yazan Tursun Bey eserine Târîh-i Ebû'l-Feth (Fethin Babasının Tarihi) adını vermiştir.

Tursun Bey'e göre; II. Mehmed, Belgrad seferi sırasında taktik icabı ricat edildiği sırada devlet adamlarının geri planda kalması teklifini kabul etmemiș ve taarruza geçmiștir. Düșman askerinden yüzde biri kadarı kaleye erișe bilecek kadar șanslı olmuștur. Osmanlı ordusu içerisinde bir bayram havası yașanmıștır. Kalenin fethedilmesine ramak kalmıș olmasına rağmen, akșam olmasından, askerin büyük kesimin yorgunluğundan, bir kesiminin de yaralı olmasından dolayı II. Mehmed Belgrad Kalesini yaraladığ hayvanına benzeterek bir dahaki seferinde alacağını ifade edip geri çekilme emri vermiştir. Dönüş sırasında düşman kralının ölüm haberi gelmiştir. Osmanlı ordusu taktik icabı ricat ederken krala Türklerin namusunu bırakarak kaçtıkları haber verilince; kral da kaleden çıkıp saldırıya katıldığı sırada bir Osmanlı askerinin okuyla yaralanmıș ve ölmüştür. Zaten II. Mehmed'in amacı da düşman kralını öldürmek olduğundan amacına ulaşmıș bir șekilde huzur içerisinde Edirne'ye dönmüștür. ${ }^{53}$

\footnotetext{
53 “Düșmenden yüz döndürmek singun nișânıdur; benim hôd elhâmdü li'llâh, el-Hakku yallû [Hak üstündür ona üstün gelinmez] hükmince ikbâlüm âlîdir, idbâr nasîb-i düșmendür"didi. Dahı cıdâsın eline aldı, mukâbiline gelen kâfir tulpına depdi, seçilüp ileri gelen afâritten üçini toprağa saldı. ...Bunı görüp ehl-i İslâm'un atlusı ve yayası yir yir at salup kâfrin yüzin döndürdiler. Bir sahrâda ki ivec ü emtâsı deresi ve depesi yok, dümdüz ovadur-bunun gibi yirde, cebelü piyâde galeyân-ı șarâb ve harâret-i hareket ü âfitâb ile cebe kasmış, cânı burnına gelmiş zebun kâfiri ele aldılar... Hâsıla at ayağı altına alup, leked-kûb-ı âdem ittiler. Şöyle ki, yüzde biri kal'aya kurtulmadl. Ehl-i İslâm arasında bayram oldı. Kal'a dahı ednâ hamle ile feth olunmak ihtimâli karîb idi; ammâ, gice yitiști. Pâdişâh-ı âtıfet-şi'âr bu feth-i mübîn ile iktifâ itti, "Kullarum yorgun ve ba'zı mecruh oldl, kal'a hod av kılınmıs șikârumdur, vakt iki olsun" diyü "el-avdü ahmed/dönüș en iyisi en övülmeye değeridir" ile amel idüp, bu halvet-i gazâvet ile göc buyurdı. Birkaç günden ki pâdişâh-ı muzaffer kendü memleketlerine sâye-i devlet saldı,
} 


\begin{abstract}
II. Mehmed zamanında Akdeniz'de hâkimiyet tesis etmek adına bir yandan Gedik Ahmed Paşa Pulya'nın fethi için görevlendirilmiş, diğer yandan da Mesih Paşa Rodos'un fethiyle görevlendirilmiștir. Tursun Bey, Pulya'yı İstanbul'un bir benzeri olarak tarif eder. Pulya'nın fethi büyük bir sevince neden olurken, Rodos üzerine yapılan seferin neticesi olarak çok fazla ganimet ele geçirildiği şu şekilde ifade edilir ve elde edilen netice bir fetih/zafer gibi takdim edilir: "Envâ'-ı ganâyim ü fütühât husûle mevsûl oldı."54

Tursun Bey, burada Belgrad Seferini bir zafer gibi göstererek Fatih Sultan Mehmed zamanına dair olumlu bir geçmiş tablosu çizmeye çalışmıştır. Kanûnî Sultân Süleyman, onuncu Osmanlı padişahı olarak tahta çıktığında ilk işi büyük ceddi Fatih Sultan Mehmed zamanında alınamayan Belgrad ve Rodos üzerine sefer tertip etmek olur. Kanûnî Sultân Süleyman, devrini yazan Celâlzâde Mustafa Çelebi de bir zamanlar Tursun Bey'in yaptığı gibi bu iki yerin fethini anlatırken hem Belgrad'ın hem de Rodos'un fethinin Fatih Sultan Mehmed'e nasip olmadığını, hatta Belgrad seferi sırasında Hunyadi János'un saldırısı karşısında Osmanlı ordusunun geri çekilmek zorunda kaldığını ifade edecektir. Aynı şekilde Mesih Paşa'nın da herhangi bir başarı elde edemeden Rodos'tan ayrıldığını ifade edecektir. 55
\end{abstract}

\footnotetext{
haber yetişti ki, kıral-ı mel'ûn cehenneme göç itti. Mergine ve cihânı terkine bu sebeb bu ki, şol vakt ki bendegân-ı devlet muhâda'a idüp döner döner gibi ittiler, kırala didiler ki, "Türk terk-i nâmus idüp sındı." Bu i'tikâd üzere çün mest idi, tehevvür idüp, ol dahı kal'adan çıkup birez meydana yörimiş, dönüp çıktuğı burgâzı gözleyüp kaçarken, bir gâzi ardından bir tîr-i merg-te'sîr yetiştürmiş, ol cerâhetten müsâfir-i sefer-i sakar düşmiş..."Kezâlike yef'alü'llâhü'z-zâlimîn/Allah zâlimleri böyle yapar." Çün matlûb-ı pâdişâh katl-i rakîb idi ve bi-hamdi'llâh müyesser oldl, pes vasl-ı habîb-ki nev-arûs-ı pürnâz-ı memleket-i Lâz'dur-tahsîlinin esbâbı ve tarîkı mübâșereti içün, ol şâh -ı pîrûz râyeti mansûr-devlet, inân-ı şemâl-şitâbı ve rikâb-ı zemîn-sebâtı semend-i âlem-neverd üzre mutlak u mübrem idüp, dârü's-saltana Edirne'ye ...nüzul buyurdı." Tursun Bey, Târîh-i Ebu'l-Feth, haz. Mertol Tulum, İstanbul Fetih Cemiyeti Yayınları, İstanbul, 1977, s. 7884.

54 Tursun Bey, Târîh-i Ebu'l-Feth, haz. Mertol Tulum, İstanbul Fetih Cemiyeti Yayınları, İstanbul, 1977, s. 179-180.

55 Celâlzâde Mustafa Çelebi, Geschicte Sultan Süleyman Kanunis von 1520 bis 1557, oder /Tabakâtü'l- Memâlik ve Derecâtü'l-Mesâlik (Tıpkı basım kısmı), neşr. Petra Kappet, Franz Steiner Verlagi Wiesbaden, 1981, 48b, 65a-67a.
} 


\section{Sonuç}

Tarih, insanoğlunun mazi, hal ve istikbal yolculuğunda, hali anlamasını ve istikbale dair tasavvurlar geliştirmesini sağlar. Bu anlamda her ne kadar tarih, kollektif hafiza olarak kabul edilmese de tarihin de insanlık için bir hafıza ișlevi görür. Modern dönemler öncesinde tarih genellikle siyasi tarih anlaşıldığından ve siyasi tarih de genelde iktidara sahip olan şahısların hayat hikayelerini, icraatlarını anlattığından iktidar sahipleri tarih yazım alanını kontrol etme isteğinde olmuşlardır. Bu bazen tarih yazdırarak, arzu ettikleri hadiselerin arzu ettikleri șekilde kayıt altına alınmasını sağlamak șeklinde olduğu gibi bazen de yazılmıș metinlerin yakılıp yok edilmesi suretiyle geçmişin bilgisine unutturmaya çalışan bir sansür vasıtasıyla olmuștur.

Bazen de tarihçi dışarıdan bir baskı olmaksızın yazdığı eseri iktidar sahiplerine sunup dünyalık bir iltifat/atiye beklentisi içinde olduğundan sunacağı eserin beğenilmeyeceği endișesiyle ya da devlet menfaatlerini gözeterek susmayı ya da yazmamayı tercih edebilir. Bu durumda susma ya da yazmama eylemi oto sansür olarak değerlendirilebilir. Ancak susmanın ya da yazmamanın dışında var olan tarihi gerçeklik olduğundan farklı gösterilirse bu takdirde oto sansür eylemine çarpıtmada eşlik ettiği gözlemlenmektedir. Erken dönem Osmanlı tarihini yazan kronik yazarlarının bir kısmı da devlet menfaatlerini gözetmek, anılması hoș olmayan hadiseleri zikrederek hanedana zarar vermemek ya da eserlerinin devlet büyükleri tarafından beğenilmeyeceği gibi endișelerle bazı hadiseleri zikretmemeyi ya da olduğundan farklı göstermeyi amaçlamışlardır. Illk dönem kronik yazarlarının bu çabaları iyi niyetle yapılmış olsa dahi neticede oto sansür ve çarpitma olarak kabul edilebilir. Zira "tarihin gözleri doğruluktur" ve her ne kadar "sükût ikrardan" olsa da tarihçinin sükûtu daha ziyade inkârdandır.

\section{I-Ana Kaynaklar}

Ahmedî, İskendernâme, haz. Hasan Akçay, Harran Üniversitesi Sosyal Bilimler Enstitüsü Türk Dili ve Edebiyatı Anabilim Dalı, Eski Türk Edebiyatı Bilim Dalı Yayınlanmamış Yüksek Lisans Tezi, Urfa, 1999.

Angiolello, Giovan Maria, Fatih Sultan Mehmed, çev. Pınar Gökpar, Profil Yayıncılık, İstanbul, 2011. 
Anonim Kitâb-ı Tevârih-i Âl-i Osmân, haz. Vehbi Günay, Ege Üniversitesi Edebiyat Fakültesi Yayınları, İzmir, 2011.

Anonim Osmanlı Kroniği (1299-1512), haz. Necdet Öztürk, Türk Dünyası Araştırmaları Vakfı Yayınları, İstanbul, 2000.

Anonim Tevârih-i Âl-i Osman, haz. Ahmet Akgün, Marmara Üniversitesi Sosyal Bilimler Enstitüsü Tarih Bölümü Yayınlanmamış Yüksek Lisans Tezi, İstanbul, 1988.

Anonim Tevârîh-i Âl-i Osmân, haz. Ali Birbiçer, Marmara Üniversitesi Sosyal Bilimler Enstitüsü Yayınlanmamış Yüksek Lisans Tezi, İstanbul, 1989.

Anonim Tevârîh-i Âl-i Osman, haz. F. Gise, çev. Nihat Azamat, Marmara Üniversitesi Yayınları, İstanbul, 1992.

Âşıkpaşazâde, Âşıkpaşazâde Tarihi [Osmanlı Tarihi (1285-1502)], haz. Necdet Öztürk, Bilge Kültür Sanat Yayınları, İstanbul, 2013.

Celâlzâde Mustafa Çelebi, Geschicte Sultan Süleyman Kanunis von 1520 bis 1557, oder /Tabakâtü'l- Memâlik ve Derecâtü'l-Mesâlik (Tıpkı basım kısmı), neşr. Petra Kappet, Franz Steiner Verlagi Wiesbaden, 1981.

Ebu Hayr-ı Rumî, Saltuk-nâme, II, haz. Ș. Haluk Akalın, İstanbul,1988.

Enverî, Düsturnâme-i Enverî (Dil Özellikleri-Metin), haz. Betül Ademli, Sakarya Üniversitesi Sosyal Bilimler Enstitüsü Türk Dili ve Edebiyatı Anabilim Dalı Yeni Türk Edebiyatı Bilim Dalı, Yayınlanmamış Yüksek Lisans Tezi, Sakarya, 2007.

Fatih Sultan Mehmed, Kanûnnâme-i Âl-i Osman (Tahlil ve Karşılaştırmalı Metin), haz. Abdülkadir Özcan, Kitabevi Yayınları, İstanbul, 2007.

Feridun Ahmed Bey, Mecmua-yı Münşeat-ı Feridun Bey, I, Takvimhaneyi Âmire, [İstanbul], 1265-1274.

Gelibolulu Mustafa Âlî, Künhü'l- Ahbâr, II, Fatih Sultan Mehmed Devri1451-1481, haz. M. Hüdai Şentürk, Türk Tarih Kurumu Yayınları, Ankara, 2003.

Hadidî, Hadidî Tarihi [Manzum Osmanlı Tarihi] (1285-1523), haz. Necdet Öztürk, , Bilge Kültür Sanat Yayınları, İstanbul, 2015.

Hali b. İsmail, Simavna Kadısığlu Şeyh Bedreddin ve Menâkıbı, haz. Abdülbaki Gölpınarlı, Milenyum Yayıncllık, İstanbul, 2008.

Hoca Sadeddîn Efendi, Tâcü't-Tevârîh, I, İstanbul, 1279-1280.

İbn Kemâl, Tevârih-i Âl-i Osman VII. Defter, haz. Şerafettin Turan, Türk Tarih Kurumu Yayınları, Ankara, 1991.

İdris-i Bitlisî, Heșt Behişt VII. Ketibe Fatih Sultan Mehmed Devri, haz. Muhammed İbrahim Yıldırım, Türk Tarih Kurumu Yayınları, Ankara, 2013. 
Karamanlı Nişancı Mehmed Paşa, "Osmanlı Sultanları Tarihi", çev. İbrahim Hakkı Konyalı, Osmanlı Tarihleri, haz. H. Nihal Atsız, Türkiye Yayınevi, İstanbul, 1949, ss. 322-369.

Makrizî, Kitâbu's-Sülûk li Ma'rifeti Düveli'l-Mülûk, IV, 2. bölüm, haz. Said Abdulfettah Aşur, Mısır Ulusal Kütüphanesi Yayınları, Kahire, 1972.

Menâkıb-ı Hacı Bektâş-ı Veli, Vilâyet-nâme, haz. Abdülbaki Gölpınarlı, İnkılap Kitabevi, İstanbul, 1958.

Mevlâna Mehmed Neşrî, Cihânnümâ [Osmanlı Tarihi (1288-1485)], haz. Necdet Öztürk, Çamlıca Basın Yayım. İstanbul, 2008.

Mihailović, Konstantin, Bir Yeniçerinin Hatıratı, çev.- haz. Kemal Beydilli, Tarih ve Tabiat Vakfı Yayınları, İstanbul, 2003.

Müneccimbaşı Ahmed b. Lütfullah, Camiü'd-Düvel (Osmanlı Tarihi 1299-1481), haz. Ahmet Ağırakca, İnsan Yayınları, İstanbul, 1995.

Oruç Beğ, Oruç Beğ Tarihi [Osmanlı Tarihi -1288-1502], haz. Necdet Öztürk, Çamlıca Basın Yayım, İstanbul 2008.

Solakzâde Mehmed Hemdemî, Solakzâde Tarihi, İstanbul, 1297/1298.

Spandunis, Theodoros, Osmanlı Sultanları, haz. Donald M. Nicol, çev. Necdet Balta, Kitap Yayınevi, İstanbul, 2015.

Şükrullah, Behcetü't-Tevârîh/Tarihin Aydınlığında, haz. Hasan Almaz, Mostar Yayınları, İstanbul, 2013.

Şükrullâh, Behcetü't-Tevârîh-Tarihin Aydınlığında, çev. Hasan Almaz, Mostar Yayınları, İstanbul, 2013.

Tagrîberdî, en-Nücûmu'z-Zâhire fî Mülûk Mısır ve'l-Kâhire, XIV, Dâru'lKütübi'lllmiyye, Beyrut, 1992.

Tursun Bey, Târîh-i Ebu'l-Feth, haz. Mertol Tulum, İstanbul Fetih Cemiyeti Yayınları, İstanbul, 1977.

\section{II-Araştırma ve İnceleme Eserler}

[Yinanç], Mükrimin Halil, "Feridun Bey Münşeatı," Tarih-i Osmani Encümeni MecmuasI] [TOEM], XI-XIII/62-77, İstanbul, 13361339, ss. 161-168.

[Yinanç], Mükrimin Halil, "Feridun Bey Münșeatı," Tarih-i Osmani Encümeni Mecmuasi] [TOEM], XIV/1, (78), İstanbul, 1340, s. 37-46.

[Yinanç], Mükrimin Halil, "Feridun Bey Münşeatı," Tarih-i Osmani Encümeni MecmuasI] [TOEM], XIV/2, (79), İstanbul 1340, ss. 95-104. 
[Yinanç], Mükrimin Halil, "Feridun Bey Münşeatı," Tarih-i Osmani Encümeni MecmuasI] [TOEM], XIV/4, (81), İstanbul 1342, ss. 216-226.

Akça, Gürsoy - İnce, Yunus, Klasik Osmanlı Çağında Tarih, Meşruiyet ve Rüya, Palet Yayınları, Konya, 2015.

Anhegger, Robert, "Fatih Devrinde Yazılmış Farsça Manzum Bir Eser, Mu'âli'nin Hünkârnâmesi", Tarih Dergisi, I, İstanbul, 19491950, ss. 145-166.

Assmann, Jan, Kültürel Bellek, Eski Kültürlerde Yazl, Hatırlama ve Politik Kimlik, çev. Ayșe Tekin, Ayrıntı Yayınları, İstanbul, 2015.

Báez, Fernando, Kitap Kıyımının Evrensel Tarihi, çev. Tolga Esmer, Can Yayınları, İstanbul, 2018.

Byzantion'dan Constantinopolis'e İstanbul Kuşatmaları, ed. Murat Arslan-Turhan Kaçar, İstanbul Araştırmaları Enstitüsü Yayınları, İstanbul, 2017.

Cabanel, Patrick, "Jules Michelet", Tarihçiler, der. Véronique Sales, çev. Elif Bildirici, İletişim Yayınları, İstanbul, 2016, ss. 13-35.

Ciceronis, Marcus Tullius, Ad Qintum Fratrem Dialogi Tires de Oratore, ed. James Luce Kingsley, Novi Porte Publisher, Basım yeri yok 1839.

Connerton, Paul, Toplumlar Nasıl Anımsar?, çev. Alaeddin Şenel, Ayrıntı Yayınları, İstanbul, 2014.

Draaisma, Douwe, Unutmanın Kitabı, Rüyalarımızı Neden Hemen Unuturuz, Anılarımız Neden Sürekli Değişir?, çev. Dilman Muratoğlu, Yapı Kredi Yayınları, İstanbul, 2012.

Franklin, Benjamin, Poor Richard's Almanac, Barnes\&Nobles Book, New York, 2004.

Freud, Anna, Ben ve Savunma Mekanizmaları, çev. Yeşim Erim, Metis Yayınları, İstanbul, 2015.

Freud, Sigmund, Bastırma ve Bastırılanın Geri Dönüşü, çev. Oya Kasap, Telos Yayınları, İstanbul, 2015.

Geary, Patrick J, Phantoms of Remembrance: Memory and Oblivion at the end of the First Millennium, Princeton University Press, Princeton-New Jersey, 1994.

Halbwachs, Maurice, Hafizanın Toplumsal Cerçeveleri, (Kısaltma: Hafıza), çev. Büşra Uçar, Heretik Yayınları, Ankara, 2016.

Hamlan, Talât Sait, Güneş-Tanrı ile Sevgi Ozanı Eski Mısır'dan Şiirler, Yapı Kredi Yayınları, İstanbul 1995.

İnce, Yunus, "'Klasik Dönem Osmanlı Tarih Yazımında Moğol İmgesi", Köktürk Yazısının Okunuşunun 125. Yılında Orhun'dan 
Anadolu'ya Uluslararası Türkoloji Sempozyumu 1-7 Haziran 2018 Ulanbator-Moğolistan, Bildiriler Kitabı, II, Kesit Yayınları, İstanbul, 2018, ss. 926-940.

Kraelitz, Friedrich von, "İlk Osmanlı Padişahlarının Isdar Etmiş Oldukları Bazı Beratlar," Tarih-i Osmani Encümeni Mecmuası [TOEM], V/28, İstanbul, 1330 [1914], ss. 242-243.

Kutsal Kitap-Eski ve Yeni Antlaşma (Tevrat, Zebur, İncil), Kitab-1 Mukaddes Şirketi Yayınları, İstanbul, 2008.

Polastron, Lucien X., Kitap Yakmanın Tarihi, çev. Aziz Ufuk Kılıç, Everest Yayınları, İstanbul, 2011.

Ricoeur, Paul, "The Contribution of French Historiography to the Theory of History" Oxford Clarendon Press- Oxford University Press, New York, 1980.

Spiers, Hugo J. - Maguire1, Eleanor A. - Burgess, Neil "Hippocampal Amnesia", Neurocase,VII, Oxford University Press, London, 2001, pp. 357-382.

Stavrides, Theoharis, The Sultan of Vezirs, The Life and Times of The Ottoman Grand Vezir Mahmud Pasha Angelović (1453-1474), Brill, Leiden-Boston-Köln, 2001.

Tezcan, Baki, "Erken Osmanlı Tarih Yazımında Moğol Hatıraları", Osmanlı Sarayında Tarih Yazımı, çev. Zeynep Nevin Yelçe, ed. H. Erdem Çıpa-Emine Fetvacı, Tarih Vakfi Yurt Yayınları, İstanbul, 2014, ss. 27-45.

Tosh, John, Tarihin Peşinde, Modern Tarih Çalışmasında Hedefler, Yöntemler ve Yeni Doğrultular, çev. Özden Arıkan, Tarih Vakfı Yurt Yayınları, İstanbul, 2005.

Traverso, Enzo, Geçmişi Kullanma Klavuzu, Tarih, Bellek, Politika, çev. Ișık Ergüden, Versus Yayınları, İstanbul, 2009.

Troillot, Michel-Rolph, Geçmişi Susturmak Tarihin Üretilmesi ve İktidar, çev. Sezai Ozan Zeybek, İthaki Yayınları, İstanbul, 2015.

Uzunçarșıll, İsmail Hakkı, "Fatih Sultan Mehmed'in Vezîri Âzamlarından Mahmud Paşa ile Şehzade Mustafa'nın Arası Neden Açılmıștı", Belleten, XXVIII/112, Ankara, 1964, ss. 719728.

Uzunçarșıll, İsmail Hakkı, "Osmanlı Tarihinde Gizli Kalmıș veya Şüphe ile Örtülü Bazı Olaylar", Belleten, XLI/163, Ankara, 1977, ss. 507-554. 
Yunus INCE

368 | Celal Bayar Üniversitesi Sosyal Bilimler Dergisi - Cilt: 17, Sayı: 1, Mart 2019 